\title{
PERSPEKTYWY POZYSKIWANIA GAZU ZIEMNEGO ZE ZLÓŻ NIEKONWENCJONALNYCH NA UKRAINIE
}

\begin{abstract}
Pozyskiwanie gazu ziemnego ze złóż niekonwencjonalnych na obszarze Ukrainy może stanowić znaczące wsparcie dla państwa starającego się uniezależnić od dostaw surowca ze Wschodu. Za sprawą tego surowca, wydobywanego z przewidywanym (nierzadko nazbyt optymistycznie) zyskiem, mogłaby polepszyć się za pozycja Ukrainy w jej staraniach zarówno o niezależność i terytorialną integralność, jak i o dywersyfikację źródeł dostaw gazu ziemnego. Warunkiem jest jednakże opłacalność wydobywania gazu ziemnego ze złóż niekonwencjonalnych. W artykule przedstawiono szacunki dotyczące ukraińskich zasobów gazu oraz zapotrzebowanie na surowiec $\mathrm{w}$ tym państwie. Ukazano również działania Ukrainy, zmierzające do dywersyfikacji dostaw surowca i choć częściowego uniezależnienia się od Rosji. Przedstawiono także aktywność zachodnich przedsiębiorstw, które zajmują się poszukiwaniem gazu z łupków, a także najważniejsze złoża surowca, na obszarze których odbywają się prace. Z uwagi na znaczenie Rosji, będącej kluczowym dostawcą gazu na Ukrainę, w artykule ukazano również krytyczne stanowisko Moskwy wobec pozyskiwania gazu z łupków na Ukrainie. Jak zostało to udowodnione, zajęcie Krymu, a także wciąż możliwe odłączenie się od Ukrainy innych terytoriów niewątpliwie osłabi bezpieczeństwo gazowe tego państwa, przynosząc znaczące korzyści Rosji. W artykule przedstawione zostały także perspektywy pozyskiwania gazu z łupków na Ukrainie, w szczególności zaś sprzeciw określonych sił politycznych i społecznych. Co istotne, w artykule wskazano również na znaczenie innych rodzajów gazu niekonwencjonalnego: gazu ściśniętego oraz metanu z pokładów węgla.

Słowa kluczowe: Ukraina, gaz łupkowy perspektywy.
\end{abstract}

\section{WSTĘP}

Na przełomie pierwszej i drugiej dekady XXI wieku w USA nastąpił boom łupkowy, dający wielu państwom, zmagającym się $\mathrm{z}$ niedoborem gazu ziemnego, nadzieję na poprawę stanu bezpieczeństwa gazowego. Zważywszy na związany nierzadko $\mathrm{z}$ koniecznością importu surowca, problem uzależnienia od kluczowego dostawcy, część państw dostrzegła w możliwości pozyskiwania gazu ziemnego ze złóż łupkowych ansę na osłabienie istniejącej zależności. W przypadku państw Europy Środkowo-Wschodniej najbardziej znaczącym eksporterem gazu ziemnego jest Rosja, często wykorzystująca posiadaną pozycję jako instrument ekonomicznego i politycznego nacisku. Ofiarą nacisku ze strony Rosji, wykorzystującej swoją pozycję kluczowego dostawcy gazu ziemnego, wielokrotnie padała Ukraina.

Odkrycie łupków gazonośnych na obszarze Ukrainy może stanowić znaczące wsparcie dla państwa starającego się uniezależnić od dostaw surowca ze Wschodu. Jest to szczególnie istotne $\mathrm{w}$ okresie bardzo poważnego napięcia pomiędzy Rosją i Ukrainą,

\footnotetext{
${ }^{1}$ Dr Łukasz Wojcieszak, Politechnika Świętokrzyska, al. Tysiąclecia Państwa Polskiego 7 , 25-314 Kielce, e-mail: lwojcieszak@tu.kielce.pl
} 
kiedy to znaczenie gazu jako elementu nacisku jeszcze bardziej wzrosło. Władze w Moskwie starają się uzyskać dominację nad swoim zachodnim sąsiadem nie tylko za sprawą posiadanego potencjału militarnego (który umożliwił np. aneksję Krymu), lecz również za pomocą zasobów surowcowych, których Ukraina nie posiada w wystarczających ilościach. Efektywność ekonomiczna procesu wydobycia gazu ziemnego z pokładów tych kopalin może polepszyć pozycję państwa walczącego zarówno o niezależność i terytorialną integralność, jak i o dywersyfikację źródeł otrzymywanego gazu ziemnego.

Mając na uwadze istniejące uwarunkowania, należy założyć, że istnienie na Ukrainie znaczących zasobów gazu z łupków, mogących częściowo pokryć zapotrzebowanie tego państwa na surowiec jest faktem. Należy przy tym wskazać, jaką aktywność w poszukiwaniu gazu z łupków wykazują zachodnie koncerny. Istotne jest również przedstawienie reakcji Rosji na próby pozyskiwania gazu łupkowego przez Ukrainę, a także barier, stojących na drodze pozyskiwaniu surowca. Ważne jest przy tym zbadanie czy gaz z łupków może zapewnić Ukrainie niezależność od Rosji oraz ustalenie, jakie skutki dla perspektyw wydobycia tego surowca przyniosła aneksja Krymu przez Rosję. Należy zaznaczyć, że w niniejszym artykule pojawiają się również odniesienia do innych rodzajów gazu niekonwencjonalnego: gazu ściśniętego (zamkniętego w nieporowatych piaskowcach) i metanu z pokładów węgla.

\section{UKRAIŃSKI ZASOBY GAZU A JEJ ZAPOTRZEBOWANIE NA} SUROWIEC

Pod koniec 2014 roku zasoby gazu ziemnego w złożach konwencjonalnych na Ukrainie były szacowane na około $0,6 \mathrm{bln} \mathrm{m}^{3}$, produkcja - 18,6 $\mathrm{mld}^{3}$, natomiast zużycie - 38,4 $\mathrm{mld}^{3}{ }^{2}$. Gaz ziemny ma dominujący udział w ukraińskim bilansie źródeł energii pierwotnej. Krajowe wydobycie gazu ziemnego, po osiągnięciu szczytu w 1975 roku $^{3}$ (ponad $68 \mathrm{mld}^{3}$ ), stopniowo malało, stabilizując się w ostatnich latach na poziomie około $20 \mathrm{mld} \mathrm{m}^{3}$. Poziom konsumpcji spadał ze $118 \mathrm{mld} \mathrm{m}^{3} \mathrm{w} 1991$ roku do niespełna $55 \mathrm{mld} \mathrm{m}^{3} \mathrm{w} 2012$ roku i poniżej $40 \mathrm{mld} \mathrm{m}^{3} \mathrm{w} 2014$ roku. Mimo to Ukraina pozostaje znaczącym konsumentem gazu: trzynastym na świecie i piątym w Europie. Największym konsumentem gazu są: przemysł (40\% w strukturze krajowego zużycia) oraz mieszkańcy (ponad 30\%). Około 20\% zużycia przypada na systemy ciepłownicze, w tym dostawy dla jednostek budżetowych i komunalnych, aż 9\%: na ,straty technologiczne i inne" (generowane m.in. w procesie przesyłu surowca). Mimo spadku w latach 20082012 ilości importowanego gazu, szybki wzrost jego cen powodował ogromną zwyżkę

\footnotetext{
${ }^{2} \mathrm{BP}$ Statistical Review of Global Energy, June 2015, https://www.bp.com/content/dam/bp/pdf/energy-economics/statistical-review-2015/bp-statisticalreview-of-world-energy-2015-full-report.pdf (29.03.2016).

${ }^{3}$ Warto zaznaczyć, że już w czasach radzieckich na złożach na terytorium Ukrainy była stosowana technologia szczelinowania. Pierwsze szczelinowanie pokładu węgla miało miejsce w 1954 roku w Donbasie, M. Honczar, Pierwsze kroki $w$ nieznane. Perspektywy wydobycia gazu niekonwencjonalnego na Ukrainie, „Komentarze OSW”, 27.04.2013, http://www.osw.waw.pl/pl/publikacje/komentarze-osw/2013-04-27/pierwsze-kroki-w-nieznaneperspektywy-wydobycia-gazu (01.06.2014).
} 
rocznych kosztów importu: z niespełna 4 mld USD w 2005 roku do 14 mld USD w latach 2011-2012

Jak wskazano, ukraińska gospodarka jest nadal bardzo energochłonna, choć od lat zapotrzebowanie to zmniejsza się - jeszcze w 2004 roku państwo to było piątym importerem gazu na świecie ${ }^{5}$. Ukraina importuje około dwie trzecie swojego gazu z Rosji po cenie, która wynosiła średnio około 415 USD za 1 tys. $\mathrm{m}^{3}{ }^{6}$ Spadek zapotrzebowania Ukrainy na „błękitne paliwo” jest spowodowany nie tylko większym zużyciem węgla, lecz także kryzysem jaki silnie uderza w to państwo oraz rosnącymi cenami gazu dla jego użytkowników, co spowodowało naturalną reakcję związaną ze zmniejszeniem konsumpcji (optymalizacją).

Problemem Ukrainy są trudności z wydobywaniem gazu ziemnego ze złóż własnych. Wielkość zasobów surowca, zwłaszcza w basenie Morza Czarnego i Azowskiego, oceniana jest na 1,2-1,5 bln $\mathrm{m}^{3}$, jednak istnieje kilka przeszkód dla szybkiego zwiększenia wydobycia. Część złóż należy do grupy trudno dostępnych, co wymaga nowoczesnych i kosztownych technologii, którymi Ukraina nie dysponuje. Efektywnemu korzystaniu z zasobów nie sprzyja również korupcjogenny klimat inwestycyjny, a także duże rozdrobnienie złóż, zwiększające potencjalne koszta wydobycia z powodu konieczności ich osobnej eksploatacji. Należy także wspomnieć o takich przeszkodach, jak obecność min wojskowych oraz miejsc startu rakiet wojskowych, co odstrasza potencjalnych inwestorów. Do wybuchu konfliktu rosyjsko-ukraińskiego problemem dla zwiększenia wydobycia gazu ziemnego było również przeciąganie się procesu delimitacji i demarkacji granicy morskiej między oboma państwami ${ }^{7}$. Toczący się konflikt dodatkowo osłabił zdolność Ukrainy do szybszego pozyskiwania tak potrzebnego jej paliwa.

Według amerykańskiej Energy Information Administration (EIA), Ukraina posiada jedne z największych zasobów gazu łupkowego w Europie, szacowanych na około 1,2 bln $\mathrm{m}^{3}{ }^{8}$ Według innych szacunków, Ukraina zajmuje czwarte miejsce w Europie (po Rosji,

\footnotetext{
${ }^{4}$ A. Sarna, Gazowa strategia Kijowa: między Gazpromem a realna dywersyfikacja, „Komentarze OSW", 15.07.2013, http://www.osw.waw.pl/pl/publikacje/komentarze-osw/2013-07-15/gazowastrategia-kijowa-miedzy-gazpromem-a-realna (22.05.2014). Gaz pełni na Ukrainie istotną funkcję socjalną, gdyż zapewnienie obywatelom taniego paliwa jest uważane przez władze za niepisany warunek zachowania względnej stabilności społecznej, ibidem. Warto zauważyć, że na początku lat 90. zużycie gazu ziemnego na Ukrainie sięgało aż $115 \mathrm{mld} \mathrm{m}^{3}$ rocznie. W kolejnych latach zużycie tego paliwa systematycznie spadało do $68,6 \mathrm{mld} \mathrm{m}^{3} \mathrm{w}$ roku 2000. Jednocześnie wydobycie własne spadło z 28,1 mld m³ w roku 1990 do $18 \mathrm{mld} \mathrm{m}^{3}$ w 2000 roku, T. Kapuśniak, Pozycja ekonomiczna Ukrainy, [w:] Ukraina $w$ stosunkach międzynarodowych, red. M. Pietraś, T. Kapuśniak, Lublin 2007, s. 139.

${ }^{5}$ International Energy Agency, Key World Energy Statistics 2005, Paris 2005, s. 13, za: J. Pyka, Rola Rosji w zapewnieniu globalnego bezpieczeństwa energetycznego, [w:] Bezpieczeństwo energetyczne Europy Środkowej, red. P. Mickiewicz, P. Sokołowska, Toruń 2010, s. 160.

${ }^{6}$ Reuters.com, 11.05.2012, Ukraine picks Shell, Chevron to develop shale gas fields, http://www.reuters.com/article/2012/05/11/shell-chevron-ukraine-idUSL5E8GBAE020120511 (12.05.2014).

${ }^{7}$ P. Kost, Ukraina wobec Unii Europejskiej 1991-2010, Toruń 2012, s. 171-172.

${ }^{8}$ Ukraine picks Stell... Na temat gazu łupkowego zob. A. Moenke, Wpływ rewolucji tupkowej w Stanach Zjednoczonych Ameryki na rosyjskie plany rozwou sektora LNG, [w:] Fenomen Rosji. Pamięć przeszłości i perspektywy rozwoju. Część 2: Kontekst polityczny i gospodarczy, red. J. Diec, A. Jach, Kraków 2014, s. 294 i nast.
} 
Polsce i Francji) w zakresie zasobów gazu łupkowego, którego technicznie wydobywalne zasoby wynoszą pomiędzy 1 a $1,5 \mathrm{bln} \mathrm{m}^{3}$. 9 Pojawiły się również informacje, że łączne zasoby gazu $\mathrm{z}$ łupków na obszarze Ukrainy szacowane są na około $7 \mathrm{bln} \mathrm{m}^{3}$ (co stawiałoby to państwo na trzecim miejscu w Europie, po Polsce i Norwegii) ${ }^{10}$. Wspomnieć należy jednak o danych IHS Cambridge Energy Research Associates, dotyczących surowca ze źródeł niekonwencjonalnych, które miałyby wynosić 11,5 bln $\mathrm{m}^{3}{ }^{11}$ przy czym znaczący udział miałby w tej liczbie metan z zasobów węgla.

Według prognozy, zawartej w Energetycznej strategii Ukrainy na okres do 2030 roku, wydobycie gazu ziemnego w 2020 roku wyniosłoby $23,7 \mathrm{mld} \mathrm{m}^{3}$, w 2025 roku $-29,8 \mathrm{mld}$ $\mathrm{m}^{3}$, a w 2030 roku $-44,4$ mld $\mathrm{m}^{3}$ surowca rocznie. Według wspomnianej prognozy, w

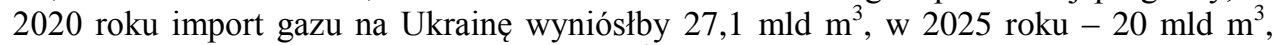
natomiast w 2030 roku - jedynie $5 \mathrm{mld}^{3}$. Zużycie gazu ziemnego przez Ukrainę w trzeciej dekadzie XXI w. może wynosić około 46-47 mld $\mathrm{m}^{3}$. Według innej prognozy, również zamieszczonej w Energetycznej strategii Ukrainy, konsumpcja oscylowałaby corocznie (do 2030 roku) wokół $50 \mathrm{mld} \mathrm{m}^{3},{ }^{12}$ choć istnieją również odmienne szacunki ${ }^{13}$. W perspektywie do 2030 roku przewidywany jest spadek udziału przemysłu w zestawieniu najbardziej energochłonnych sektorów gospodarki ${ }^{14}$. Wraz ze spodziewanym wzrostem wykorzystania węgla, będzie to prowadziło do łatwiejszego pokrycia

${ }^{9}$ G. Zachmann, D. Naumenko, Evaluating the options to diversify gas supply in Ukraine, Berlin/Kyiv, February 2014, s. 13.

${ }^{10}$ T. Marocchi, T. Fedirko, Shale gas in Poland and Ukraine: a great potential and an uncertain future, „Pecob-Business Reports”, May 2013, s. 5.

11 Ukraine Special Report, Natural Gas and Ukraine's Energy Future, February 2012, s. 2, http://s05.static-shell.com/content/dam/shell-new/local/country/zaf/downloads/pdf/research-

reports/Ukraine-Policy-Dialogue-report.pdf (14.05.2014).

${ }_{12}$ Center EIR, Центр досліджень енергетики, 10.09.2013, Енергетична стратегія України на період до 2030 року (проект), s. 9-16, http://eircenter.com/ua-analiitika/energetichna-strategiyaukrayini-na-period-do-2030-r-proekt (20.05.2014). Udział gazu ziemnego w bilansie energetycznym Ukrainy zmniejszył się w od $47 \%$ całkowitego zużycia energii pierwotnej w 2000 roku do $40 \% \mathrm{w}$ 2010 roku. Zapotrzebowanie na gaz zmniejszyło się z 76,4 $\mathrm{mld} \mathrm{m}^{3} \mathrm{w} 2005$ roku do 59,3 $\mathrm{mld} \mathrm{m}^{3} \mathrm{w}$ 2011 roku, Ukraine 2012, International Energy Agency 2012, s. 101

${ }^{13}$ Poszczególne wyliczenia różnią się niekiedy znacznie. Według optymistycznych prognoz IHS CERA po 2030 roku produkcja gazu, łącznie ze złóż tradycyjnych i niekonwencjonalnych, może sięgnąc nawet $73 \mathrm{mld} \mathrm{m}^{3}$. Wymagać to jednak będzie wielomiliardowych inwestycji, znaczącej poprawy klimatu inwestycyjnego i stabilności politycznej. Projekt Energetycznej strategii Ukrainy do 2030 roku prognozuje, że poziom produkcji gazu ziemnego wyniesie od $30 \mathrm{mld} \mathrm{m}^{3}$ do $47 \mathrm{mld} \mathrm{m}^{3}$ w 2030 roku. $\mathrm{Z}$ tego wydobycie gazu $\mathrm{Z}$ łupków ma osiągnąć poziom 6-11 mld $\mathrm{m}^{3}$ rocznie, gazu zamkniętego $\mathrm{w}$ nieporowatych piaskowcach 7-9 mld $\mathrm{m}^{3}$, metanu z pokładów węgla 1-3 mld $\mathrm{m}^{3}$, natomiast gazu ze źródeł tradycyjnych $15-24 \mathrm{mld} \mathrm{m}^{3}$. Zgodnie z prognozą IHS CERA, wydobycie gazu po 2030 roku może przewyższyć $73 \mathrm{mld} \mathrm{m}^{3}$ rocznie, głównie dzięki eksploatacji gazu ze źródeł nietradycyjnych oraz z szelfu Morza Czarnego. Istotna jest opłacalność wydobycia gazu i ochrona inwestycji; w przypadku Ukrainy wstępne szacunki kosztów wydobycia gazu łupkowego wahają się między 263 a 350 USD, M. Honczar, op.cit.

${ }^{14}$ Zob. Міністерство енергетики та вугільної промисловості України, 19.04.2006, Енергетична стратегія Украӥни на період до 2030 р., s. 92, http://mpe.kmu.gov.ua/fuel/control/uk/doccatalog/list?currDir=50358 (01.06.2014). 
zapotrzebowania na gaz przez alternatywne wobec rosyjskich źródła dostaw surowca oraz perspektywiczne wydobycie własne.

\section{DYWERSYFIKACYJNE DZIALANIA UKRAINY}

Już od 1992 roku Ukraina podejmowała próby dywersyfikacji źródeł i dostaw energii, które nie powiodły się ${ }^{15} \mathrm{~m}$. in. dlatego, iż wystąpiła niekorzystna dla Kijowa konfiguracja stosunków międzynarodowych, a także zaniechanie reform gospodarczych. Zbyt opieszale zajmowano się również ograniczeniem zużycia energii na Ukrainie ${ }^{16}$. Szansą, a zarazem koniecznością dla Ukrainy jest wykorzystywanie swojego położenia geograficznego i czerpanie korzyści z transportu surowców przez swoje terytorium. Dotyczy to w szczególności rosyjskiego i kaspijskiego gazu oraz ropy naftowej ${ }^{17}$.

Szansą dla Ukrainy jest również zacieśnienie współpracy z Zachodem, w tym zwłaszcza państwami Unii Europejskiej. Początki kooperacji w sferze bezpieczeństwa energetycznego pomiędzy Ukrainą a UE sięgają lat 90 . XX w. ${ }^{18} .1$ grudnia 2005 roku podczas szczytu UE-Ukraina podpisano memorandum w sprawie współpracy energetycznej. Poruszono $w$ nim problem integracji energetycznej pomiędzy UE i Ukrainą, skupiając się przy tym na sposobach zapewnienia bezpieczeństwa gazowego ${ }^{19}$. W marcu 2009 roku odbyła się w Brukseli konferencja „EU-Ukraine: Partners for securing gas to Europe" dotycząca modernizacji ukraińskiego systemu transportującego gaz ziemny. Ówczesna Komisarz ds. stosunków zewnętrznych i europejskiej polityki sąsiedztwa, Benita Ferrero-Waldner, podkreśliła znaczenie ukraińskiego systemu tranzytowego dla Europy, określając Ukrainę mianem ważnego partnera strategicznego ${ }^{20}$. Doniosłe znaczenie miało również spotkanie grupy wysokiego szczebla ds. połączeń gazowych w Europie Środkowej i Południowo-Wschodniej (CESEC) w lipcu 2015 roku w Dubrowniku. Wzięli w nim udział ministrowie 15 państw, w tym także Ukrainy ${ }^{21}$. Dla

${ }^{15}$ Część surowców energetycznych Rosja kupowała np. w Turkmenistanie (gaz) i Kazachstanie (ropę), R. Kęsek, Między konfliktem a dialogiem. Polityka Ukrainy wobec Federacji Rosyjskiej w latach 1997-2004, Kraków 2010, s. 172.

${ }^{16}$ J. Kozakiewicz, Rosja w polityce niepodległej Ukrainy, Warszawa 1999, s. 116.

${ }^{17}$ T. Kapuśniak, op. cit., s. 155.

${ }^{18}$ Energetyka stała się priorytetem kooperacji pomiędzy Unią Europejską i Ukrainą już w świetle Umowy o Partnerstwie i Współpracy (Partnership Cooperation Agreement - PCA), podpisanej w 1994 roku (weszła w życie w 1998 roku). Ważnym krokiem kształtowania relacji z Ukrainą było przyjęcie pierwszego Planu Działań w grudniu 1996 roku, który obejmował okres do 2002 roku. Wśród głównych priorytetów znalazła się reforma sektora energetycznego (zasadnicze znaczenie miał przesył ropy i gazu przez Ukrainę do państw europejskich), S. Sydun, Ewolucja stosunków pomiędzy Ukraina i UE, „Środkowoeuropejskie Studia Polityczne” 2010, t. 3, s. 205. Zob. M. Nowacki, Prawne aspekty bezpieczeństwa energetycznego w UE, Warszawa 2010, s. 394-395.

${ }^{19}$ Dokument ten zawiera szereg istotnych postanowień, określających ramy współpracy w sferze energetyki. Warto tu wymienić w szczególności integrację rynków energetycznych, kwestię bezpieczeństwa dostaw energii i przesyłania węglowodorów, działania na rzecz efektywności energetycznej czy promocję OZE. Co ważne, po podpisaniu memorandum UE i Ukraina corocznie dokonują przeglądu realizacji postanowień w nim zawartych. Publikowane raporty z realizacji tego memorandum stanowią istotne źródło wiedzy o problemach ukraińskiego sektora gazu, przedstawiając zarazem stan jego liberalizacji.

${ }^{20}$ S. Sydun, Ewolucja stosunków..., s. 213.

21 T. Dąborowski, Priorytety wspótpracy gazowej w Europie Południowo-Wschodniej, „Analizy OSW", $\quad$ 15.07.2015, http://www.osw.waw.pl/pl/publikacje/analizy/2015-07-15/priorytety- 
Ukrainy szczególne znaczenie posiada problem modernizacji swojego systemu transportu gazu $^{22}$, do czego wszakże potrzebne jest wsparcie, którego udzielić może Zachód.

Ważnym krokiem ku zwiększeniu bezpieczeństwa energetycznego Ukrainy była jej akcesja do Wspólnoty Energetycznej. Państwa do niej należące zobligowane są do implementacji niektórych aktów prawa wtórnego UE. Dotyczy to w szczególności regulacji dotyczących funkcjonowania rynku gazu ziemnego, jak np. dyrektywa 2009/73/WE czy też przepisów środowiskowych odnoszących się do zasad wydobywania węglowodorów (w tym również gazu łupkowego), co może mieć wpływ na pozyskiwania gazu ziemnego ze złóż niekonwencjonalnych na Ukrainie. Rozwiązania prawne istniejące w prawie UE mają kluczowe znaczenie dla zapewnienia transparentnych zasad, które rządziłyby ukraińskim rynkiem gazu. Z punktu widzenia inwestorów, zainteresowanych pozyskiwaniem gazu ziemnego ze złóż niekonwencjonalnych na Ukrainie, zasadnicze znaczenie posiada w szczególności TPA (dostęp stron trzecich do infrastruktury), rozdział operatorów systemów od innych działalności na rynku gazu (unbundling) ${ }^{23}$, niezależność operatorów systemu przesyłowego, niezależność operatora rynku czy też przejrzystość taryfowania.

Poważne znaczenie ma również infrastruktura gazowa na Ukrainie, w szczególności zaś istniejące gazociągi przesyłowe oraz magazyny gazu, posiadające zasadnicze znaczenie dla rozwoju wydobycia gazu łupkowego. Ukraina ma jedne z największych podziemnych magazynów gazu na świecie, które razem $\mathrm{z}$ obiektami na terenie okupowanego przez Rosję Krymu mogą pomieścić $31 \mathrm{mld} \mathrm{m}^{3}$ surowca (dla porównania polskie magazyny gazu mogą przechować nieco ponad $2,8 \mathrm{mld} \mathrm{m}^{3}$ gazu) ${ }^{24}$. Z tego względu Ukraina mogłaby stać się nawet zastępczym hubem gazowym dla państw Europy Środkowo-Wschodniej. Problem stanowi jednak polityczna niestabilność państwa oraz fakt, że kwestia własności tych magazynów, a także dostęp do ich pojemności wciąż jest nietransparentny.

$\mathrm{Na}$ Ukrainie zostały wprowadzone liczne regulacje prawne związane z wydobyciem kopalin ${ }^{25}$.Wydobywanie gazu ze złóż niekonwencjonalnych regulują nieliczne dokumenty. W szczególności należy wspomnieć o ustawie W sprawie zatwierdzenia

wspolpracy-gazowej-w-europie-poludniowo-wschodniej (24.10.2015). W czasie spotkania podpisano memorandum oraz plan działań na rzecz poprawy bezpieczeństwa dostaw surowca oraz integracji rynków gazowych, ibidem.

${ }^{22}$ М. М. Гончар, Енергетична безпека України: біг на місиі, [w:] Г. М. Перепелиц (ред.) Зовнішня політика України, Київ 2009, s. 138.

23 Tymczasem pomiędzy Naftohazem (państwowym producentem gazu) i Ukrtransgazem (operatorem systemu przesyłowego) brak jest unbundlingu. Fakt, że operator pozostaje w pełnej zależności od państwowego giganta niewątpliwie zniechęca inwestorów z Zachodu, pozostając przy tym w sprzeczności z dyrektywą 2009/73/WE.

${ }^{24}$ Ukraina nie będzie pompowata więcej gazu do magazynów, Portal gospodarczy Wnp.pl, 03.11.2015, http://gazownictwo.wnp.pl/ukraina-nie-bedzie-pompowala-wiecej-gazu-domagazynow,260592_1_0_0.html (29.03.2016).

${ }^{25}$ Należy w szczególności wspomnieć o takich aktach prawnych jak: Кодекс Украӥни про надра z 1994 roku, rozporządzenie Про затвердження переліків корисних копалин загальнодержавного та місиевого значення z 1994 roku czy ustawa Про нафту і газ z 2001 roku. 
Narodowego Programu zasobów mineralnych z Ukrainy na okres do 2030 roku ${ }^{26}$, która odnosi się m.in. do gazu łupkowego. W dokumencie tym zapowiedziano w szczególności prowadzenie we wskazanym okresie badań zmierzających do oszacowania istniejących zasobów. Innym istotnym aktem prawnym była Strategia energetyczna Ukrainy na okres do 2030 roku. Według tego dokumentu komercyjna produkcja gazu łupkowego na Ukrainie nie rozpocznie się do 2022 roku. Jak zaakcentowano, istotnym problemem jest wysoki koszt oraz problematyczna opłacalność produkcji ${ }^{27}$. Co ważne, dokument odnosi się również do pozyskiwania metanu z pokładów węgla, akcentując wysokie koszty tego procesu.

Celem władz w Kijowie jest zapewnienie wzrostu krajowego wydobycia oraz znacząca redukcja zależności od importu w perspektywie 2030 roku. Istotnym problemem Ukrainy stała się rewizja niekorzystnego kontraktu na import rosyjskiego gazu, zawartego w 2009 roku przez rząd Julii Tymoszenko. Ta niekorzystna umowa ${ }^{28}$, a także będący jej wynikiem wzrost dominacji Rosji nad Ukrainą, odniosła niekorzystny skutek w postaci wzrostu cen gazu dostarczanego Ukraińcom. Kijów, zdając sobie sprawę z niezwykle trudnego położenia, postanowił w zdecydowany sposób przeciwdziałać rosnącemu uzależnieniu. Jeszcze w 2010 roku ukraińskie władze zainicjowały projekt budowy terminalu LNG pod Odessą, poprzez który Ukraina chciałaby już w 2015 roku sprowadzać do $5 \mathrm{mld}^{3}$ gazu skroplonego rocznie. Po raz pierwszy w historii Ukrainy uruchomiono również dostawy zza zachodniej granicy. W listopadzie 2012 roku, w ramach dwumiesięcznego kontraktu z koncernem RWE, państwowy koncern Naftohaz rozpoczął dostawy gazu $\mathrm{z}$ terytorium Polski, kontynuowane na mocy odrębnego kontraktu, natomiast wiosna 2013 roku został uruchomiony import surowca z Węgier. Ukraińskie władze zabiegają również o import z terytorium Słowacji. Kijów podjął także działania na rzecz wzrostu wydobycia z krajowych źródeł, w tym nietradycyjnych, a także zastąpienia ukraińskim węglem importowanego gazu. W styczniu 2013 roku rząd podpisał z koncernem Shell porozumienie na pięćdziesiąt lat o rozdziale produkcji, przewidujące eksplorację m.in. ukraińskich zasobów gazu niekonwencjonalnego ${ }^{29}$.

Sposobem na uniezależnienie się od rosyjskich dostaw gazu jest poszukiwanie nowych złóż w obrębie istniejących już miejsc wydobycia lub na niezbadanych jeszcze dokładnie

26 Закон України. Про затвердження Загальнодержсавної програми розвитку мінеральносировинної бази України на період до 2030 року, http://zakon5.rada.gov.ua/laws/show/3268-17 (30.03.2016).

${ }^{27}$ Енергетична стратегія Украйни на період до $2030 \quad$ p., http://zakon5.rada.gov.ua/laws/show/1071-2013-\%D1\%80/paran4\#n4 (03.04.2016). Według dokumentu, wśród wielu barier na drodze do komercyjnej produkcji gazu łupkowego znajduje się m.in. brak wystarczającej liczby urządzeń wiertniczych, konieczność prowadzenia prac na dużych obszarach ziemi w gęsto zaludnionych obszarach czy potrzeba ograniczenia zagrożeń dla środowiska. Jak stanowi dokument, potencjał produkcji do 2030 roku może sięgnąć 6-11 mld $\mathrm{m}^{3}$, ibidem.

${ }^{28}$ Kontrakt ten zakończył najpoważniejszą z „wojen gazowych”. Umowa na dostawy gazu do końca 2019 roku została zawarta $\mathrm{z}$ formułą cenową opartą na notowaniach produktów naftowych, przyjętą w niej bardzo wysoką kwotą bazową, rocznymi dostawami na poziomie $52 \mathrm{mld} \mathrm{m}^{3}$, klauzulą take or pay, dotyczącą $80 \%$ tego poziomu oraz zakazem reeksportu zakontraktowanego gazu, Natural Gas..., s. 5.

${ }^{29}$ A. Sarna, Gazowa strategia... 
obszarach południowej Ukrainy (jak na przykład w rejonie Morza Czarnego) ${ }^{30}$. Gaz z formacji łupkowych może mieć duże znaczenie dla zwiększenia bezpieczeństwa gazowego Ukrainy ${ }^{31}$ : występujący zwłaszcza w piaskowcach gaz zamknięty oraz metan z pokładów węgla (CBM). Nie mniej ważne są jednakże starania, mające na celu zwiększenie produkcji gazu ziemnego, zastępowanie „błękitnego paliwa” rodzimym węglem oraz zapewnienie dywersyfikacji źródeł dostaw surowca $\mathrm{z}$ takich państw jak Polska czy Węgry.

Premier Ukrainy, Mykoła Azarow, stwierdził w 2013 roku, że w ciągu najbliższych dwóch-trzech lat państwo będzie mogło całkowicie uniezależnić się od dostaw gazu z Rosji, głównie dzięki surowcowi $\mathrm{Z}$ łupków, którego wydobycie powinno zostać zapoczątkowane w 2015 roku. Zdaniem eksperta Denisa Sakwy plany te sa jednak nierealistyczne $\mathrm{m}$. in. dlatego, że prace poszukiwawcze złożach łupkowych zajmą kilka lat i dopiero po zapoznaniu się z wynikami tych działań można będzie oszacować potencjał ukraińskiego gazu ze złóż niekonwencjonalnych. Inwestycje w zagospodarowanie złóż niekonwencjonalnych nie pozwolą w krótkim czasie zrezygnować z importu rosyjskiego surowca, choć w perspektywie krótkoterminowej największym alternatywnym źródłem pozyskania gazu będzie paliwo otrzymane rewersem $\mathrm{z}$ innych państw ${ }^{32}$.

Determinacja władz ukraińskich $\mathrm{w}$ realizacji projektu wydobycia gazu $\mathrm{z}$ formacji łupkowych wynikała również z zaangażowania otoczenia byłego prezydenta Wiktora Janukowycza. Było ono zainteresowane przejęciem części spodziewanych zysków, pochodzących z pozyskiwania tego gazu. Za wpływową postać związaną z otoczeniem prezydenta uchodził minister energetyki Eduard Stawicki, jeden z propagatorów rozwoju wydobycia gazu łupkowego na Ukrainie ${ }^{33}$. Zmiana władzy na Ukrainie, wybór prozachodniego kursu w polityce zagranicznej, a przede wszystkim konflikt z Rosją oznacza jednak, iż dążenie do pozyskiwania gazu niekonwencjonalnego (w tym również z formacji łupkowych) będzie jeszcze silniejsze.

\section{AKTYWNOŚĆ ZACHODNICH PRZEDSIĘBIORSTW}

W 2012 roku eksperci z USA opracowali dokument, dotyczący oceny środowiskowej i prawnej dla wydobycia gazu łupkowego, według której w ciągu 5 lat od rozpoczęcia prac,

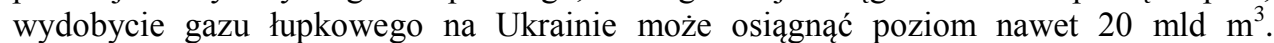
Konflikt na Ukrainie zaburzył w pewnym stopniu plan i strategię amerykańskiej polityki energetycznej; w marcu 2014 roku miały zostać podpisane umowy $\mathrm{z}$ dwiema amerykańskimi spółkami, które zaangażowały się w poszukiwanie ukraińskich złóż węglowodorów: Chevronem i Exxon Mobil, jednak planowane podpisanie umów zostało

\footnotetext{
${ }^{30}$ Natural Gas..., s. 15.

${ }^{31}$ Produkcja gazu niekonwencjonalnego na Ukrainie może osiągnąć w 2020 roku $3 \mathrm{mld} \mathrm{m}^{3}$, jeśli w sektorze gazowym nastąpią ułatwienia w dziedzinie inwestycji, International Energy Agency 2012, Ukraine 2012, s. 81.

${ }^{32}$ Portal Gazownictwo.wnp.pl, 03.10.2013, Ukraina przeszacowuje plany uniezależnienia się od gazu z Rosji, http://gazownictwo.wnp.pl/ukraina-przeszacowuje-plany-uniezaleznienia-sie-od-gazuz-rosji,208029_1_0_0.html (22.05.2014). Gotowość do dostarczania gazu Ukrainie za pomocą rewersu wyraziły Niemcy, natomiast niechętnie odniosła się do tego pomysłu Słowacja. Pomysł dostaw rewersowych spotkał się z silną krytyką ze strony Rosji.

${ }^{33}$ A. Sarna, Umowa Ukrainy z koncernem Shell o wydobyciu gazu tupkowego, „Analizy OSW”, 30.01.2013, http://www.osw.waw.pl/pl/publikacje/analizy/2013-01-30/umowa-ukrainy-zkoncernem-shell-o-wydobyciu-gazu-lupkowego (31.05.2014).
} 
odłożone w czasie. Opóźnienia w związku z nawiązaniem współpracy z Chevronem czy Exxon Mobil oraz dynamicznie zmieniającą się wewnętrzna sytuacja na Ukrainie wywołały niepokój wśród innych inwestorów, zajmujących się wydobyciem gazu łupkowego w tym państwie ${ }^{34}$.

W 2012 roku przeprowadzone zostały przetargi na poszukiwanie gazu z łupków w rejonach: Juzowskim, Oleskim i Skiwskim. W rejonie Juzowskim (znajdującym się w okolicach Charkowa i Doniecka) przetarg wygrał Shell, w rejonie Oleskim (leżącym w pobliżu Lwowa i Iwanofrankowska) - Chevron ${ }^{35}$, natomiast rejonem Skiwskim (obejmującym okolice Morze Czarne) podzieliło się kilka firm: Exxon Mobil, Shell, austriacki OMV oraz ukraińska Nadra Ukrainy. W styczniu 2013 roku w Davos, w obecności prezydenta Wiktora Janukowycza, został podpisany wspomniany już kontrakt między Shellem a Nadra Ukrainy ${ }^{36}$. Pole „Juzowskoje”, którego dotyczyło porozumienie, zawiera pokłady gazu zamkniętego w nieporowatych piaskowcach ${ }^{37}$. Rozciąga się ono na przestrzeni 7,886 tys. $\mathrm{km}^{2}$ na terytorium obwodów charkowskiego i donieckiego. $\mathrm{Na}$ pierwszym etapie prac rozpoznawczych nakłady inwestycyjne miałyby wynieść ponad $500 \mathrm{mln}$ USD, co stanowiłoby wystarczającą kwotę na pokrycie wydatków związanych z poszukiwaniami geologicznymi, w tym na wykonanie kilku odwiertów ${ }^{38}$.

Szczególną uwagę należy zwrócić na złoże oleskie, rozciągające się na obszarze o powierzchni $6324 \mathrm{~km}^{2}$ na terytorium obwodów lwowskiego i iwanofrankowskiego i będące częścią gazonośnego złoża istniejącego na terytorium Ukrainy i Polski. Według wstępnych danych, prognozowane zasoby gazu z łupków w złożu oleskim wynoszą 2,98 bln $\mathrm{m}^{3}$. Zwycięzcy już rozstrzygniętych przetargów zostali zobowiązani do zagwarantowania inwestycji na etapie wykonywania prac poszukiwawczorozpoznawczych. Zgodnie $\mathrm{z}$ warunkami przetargu, maksymalna część produkcji kompensacyjnej, z której inwestor otrzyma odszkodowanie za poniesione koszty, wyniesie $70 \%$ ogólnej wielkości wytworzonej produkcji do czasu pełnej rekompensaty

\footnotetext{
${ }^{34}$ Razemolupkach.org, Ukraiński gaz lupkowy - Ukraina traci kontrakty?, http://www.razemolupkach.org/node/1140 (12.05.2014).

35 Zob. C. I. Вилінський, Розвиток альтернативих видів палива в Украӥні. Сланцевий газ та Украӥна,

„Актуальні проблеми міжнародних відносин”, Випуск 116 (Частина I), 2013, s. 109.

${ }^{36}$ M. Wieroński, Ukraina stawia na własny gaz łupkowy, Centrum Informacji o Rynku Energii, 18.02.2013, http://www.cire.pl/item,72091,1,0,0,0,0,0,ukraina-stawia-na-wlasny-gaz-lupkowy.html (12.05.2014). Kontrakt zawarli: minister energetyki Ukrainy Eduard Stawicki oraz dyrektor holendersko-brytyjskiego koncernu Shell Peter Vozer. Podpisali oni umowę na 50 lat o rozdziale produkcji (Production Sharing Agreement, PSA) w ramach projektu wydobycia gazu łupkowego ze złoża juzowskiego (obwody charkowski i doniecki). Shell ma eksplorować złoże w partnerstwie ze spółką Nadra-Juziwska. Inwestor uzyskał natomiast bezprecedensowe w warunkach ukraińskich ulgi i zwolnienia podatkowe, A. Sarna, Umowa Ukrainy...

$37 \mathrm{Gaz} \mathrm{z}$ nieporowatych piaskowców jest najbardziej perspektywicznym rodzajem gazu niekonwencjonalnego. Szacunkowe zasoby tego surowca sięgają od 2 do $8 \mathrm{bln}^{3}$ i zalegają na głębokości 4-5 km, M. Honczar, op. cit.

${ }^{38}$ Według koncernu Shell, całość inwestycji w przemysłowe rozpoznawanie złoża oraz w budowę infrastruktury na tym terenie, może wynieść około 10 mld USD, Portal Gospodarczy wnp.pl, 03.10.2013, Ukraina przeszacowuje plany uniezależnienia się od gazu $z$ Rosji, http://gazownictwo.wnp.pl/ukraina-przeszacowuje-plany-uniezaleznienia-sie-od-gazu-zrosji,208029_1_0_0.html (02.06.2014).
} 
kosztów inwestora. Udział państwa w dochodowej części produkcji powinien wynieść nie mniej niż 15\%. Zachodni koncern otrzymał 50\% udziałów z złożach, a drugie 50\% objęła ukraińska kompania Nadra Oleska, stworzone przez państwową spółkę Nadra Ukrainy (90\% akcji) oraz firmę Geoserwis. Pozwolenia na eksploatację obydwu złóż będą ważne przez 50 lat $^{39}$.

W zachodniej części kraju złożami gazu z łupków zainteresował się austriacki RAG, a także włoska Sorgenią oraz ukraińskie Biuro Geologiczne „Lwów”. Włoska ENI nabyła 50,01\% akcji spółki Zachidhazinwest (będącej wspólnym przedsiębiorstwem Nadra Ukrainy oraz brytyjskiej Cadogan Petroleum), posiadającej dziewięć licencji na działkach o obszarze $3800 \mathrm{~km}^{2}$ i zainteresowanej poszukiwaniami gazu z łupków ${ }^{40}$. Poszukiwaniami postanowiono objąć również obszary położone w rejonie Morza Czarnego oraz Morza Azowskiego. Szczególnie istotne są prace poszukiwawcze na szelfie Morza Czarnego, choć koszty prowadzonych badań będą z pewnością znaczne, a ich opłacalność budzi wątpliwości. W przypadku poszukiwań gazu z łupków firmy będą musiały zainwestować ponad 400 mln USD na inwestycje w poszukiwania ${ }^{41}$, zanim okaże się, czy wydobycie tego gazu będzie opłacalne ${ }^{42}$. Firmy zachodnie, działające na Ukrainie, muszą się zatem zmierzyć z podobnymi problemami, co w innych państwach, jednak dodatkowym utrudnieniem jest napięta sytuacja w targanym konfliktem państwie.

\section{STANOWISKO ROSJI}

Rosja od początku istnienia niepodległej Ukrainy dostarcza jej gaz ziemny oraz ropę naftową, a więc surowce energetyczne, określane $\mathrm{z}$ racji ich znaczenia jako strategiczne. Powstała zależność, już na początku lat 90. XX w. wywoływała ukraińsko-rosyjskie spory, a ze strony Kijowa nie brak było oskarżeń, że Moskwa usiłuje za pomocą surowców ponownie skolonizować Ukrainę ${ }^{43}$. Częste podnoszenie przez Rosję cen za przesyłanie Ukrainie ropy naftowej i gazu ziemnego było realizowanie $\mathrm{z}$ pełną świadomością co do rzeczywistego stanu ukraińskich finansów i niemal całkowitego braku możliwości płatniczych Kijowa ${ }^{44}$. Z drugiej strony, tranzyt przez niepewną Ukrainę stał się zresztą jedną z przyczyn budowy Gazociągu Północnego i Południowego, które dostarczając surowiec do odbiorców na zachodzie Europy, mają omijać państwa nie zawsze przychylne rosyjskiej polityce. Rosyjska „pipeline diplomacy” 45 napotyka jednak

\footnotetext{
${ }^{39}$ M. Honczar, op. cit. Co istotne, sukces koncernu Chevron w Polsce będzie stymulował rozwój projektu na Ukrainie, natomiast fiasko polskiego projektu doprowadzi do analogicznych skutków i na Ukrainie. Rozwój wydobycia gazu niekonwencjonalnego na Ukrainie również w pewnej mierze będzie wpływać na sytuację w Polsce, ibidem.

${ }^{40}$ Ibidem.

${ }^{41}$ Warto przy okazji zauważyć, iż opłaty przetargowe na Ukrainie wynoszą odpowiednio: 60 tys. USD za przetarg oraz 10 tys. za pakiet informacji geologicznej, EIA/ARI World Shale Gas and Shale Oil Resource Assessment, Arlington, June 2013, s. 323.

${ }^{42}$ T. Marocchi, T. Fedirko, op. cit., s. 5,

${ }^{43}$ W. Gil, N. Gil, Stosunki Polski z Ukraina w latach 1989-1993, Toruń-Poznań 1994, s. 50.

${ }^{44}$ J. Kozakiewicz, op. cit., s. 107. Spory gazowe pomiędzy Ukrainą i Rosją negatywnie wpływały na poziom bezpieczeństwa gazowego wielu państw członkowskich Unii Europejskiej, zob. S. Andoura, Security of Supply and the External Dimension of a European Energy Policy, „Studia Diplomatica" 2007, vol. LX, no 2, s. 67 i nast.

45 Jej istota sprowadza się do wykorzystania w polityce energetycznej uwarunkowań geopolitycznych, infrastruktury przesyłowej oraz przerw w dostawach surowców (lub zagrożenia
} 
w ostatnim czasie na silny opór ze strony państw, będących jednocześnie odbiorcami gazu ze wschodu oraz krajami tranzytowymi. Wysiłki zmierzające do dywersyfikacji dostaw surowca oraz poszukiwań własnych zasobów gazu czynią liczne państwa Europy Środkowo-Wschodniej, w tym także Ukraina ${ }^{46}$.

W drugiej dekadzie XXI w. coraz wyraźniej zaczęły się zaznaczać procesy integracyjne przestrzeni poradzieckiej, w szczególności zaś dążenie do powstania Unii Eurazjatyckiej, łączącej byłe republiki związkowe ZSRR pod egidą Rosji. Spośród tych republik kluczowe znaczenie posiada Ukraina, bez udziału której trudno wyobrazić sobie odbudowę imperialnej potęgi Rosji ${ }^{47}$. W celu przekonania Ukrainy do przyłączenia się do Unii Celnej prezydent Władimir Putin zaproponował jej niższe ceny gazu (miało to miejsce także przed wybuchem rosyjsko-ukraińskiego konfliktu w 2014 roku) ${ }^{48}$. Kryzys, jaki wywołało odsunięcie od władzy prezydenta Janukowycza, zajęcie Krymu, a wreszcie konflikt władz Ukrainy z separatystami, uniemożliwiły de facto realizację integracyjnych planów Kremla. „Subtelny” środek nacisku, jakim jest „broń gazowa”, został w 2014 roku zastąpiony przez siłę militarną, gdzie wszakże również uwidoczniła się oczywista dysproporcja sił obu państw.

Podejmowane od lat (choć ze zmiennym szczęściem) ukraińskie próby zmniejszenia gazowej zależności od Rosji, stanowiły dla tej ostatniej znaczące zagrożenie. „Rewolucja łupkowa" w USA i Europie odbierana jest na Kremlu jako niebezpieczeństwo dla stabilności rosyjskiej gospodarki, całkowicie uzależnionej od eksportu swoich surowców energetycznych. Rosyjskie media rozpoczęły nawet kampanię propagandową pod hasłem „gaz łupkowy - to ekologiczna katastrofa”, a dziennikarze państwowej telewizji Rossija udali się do USA w poszukiwaniu przeciwników wydobywania gazu z łupków. Inne prorządowe stacje często demonstrują zaś wizje „globalnej ekologicznej katastrofy”, do której miałoby dojść w przypadku przemysłowego wydobywania gazu z łupków w Europie $^{49}$. Warto zauważyć, że w powstrzymaniu pozyskiwania gazu $\mathrm{z}$ łupków niemałą rolę mogą odegrać ekolodzy. Rosja ze swej strony wspiera działalność organizacji sprzeciwiających się sposobowi pozyskiwania surowca. Rozpowszechniane są również artykuły krytycznie odnoszące się do techniki szczelinowania hydraulicznego ${ }^{50}$.

Należy dodać, iż zablokowanie wydobycia gazu łupkowego leży w interesie wielu podmiotów, dążących do zachowania status quo „struktury biznesowej” na europejskim rynku gazu. Wydobycia tego surowca mogą obawiać się obecni eksporterzy błękitnego

ich przerwaniem) do kształtowania polityki wobec poszczególnych państw, por. M. Bodio, Polityka energetyczna w stosunkach między Unią Europejska a Federacją Rosyjska w latach 2000 -2008, Warszawa 2009, s. 138-139.

46 Polityka Kijowa sprowadzała się de facto do minimalizowania negatywnych skutków zmieniających się warunków dostaw surowca z Rosji i Azji Centralnej poprzez wykorzystywanie rosyjskiego uzależnienia od tranzytu przez Ukrainę, blokowanie prób przejęcia kontroli nad ukraińskimi gazociągami oraz zabiegów o wsparcie Zachodu w sporach z Rosją, Natural Gas..., s.5. ${ }^{47}$ Zob. Z. Brzeziński, Wielka szachownica, Warszawa 1999, s. 46.

${ }^{48}$ R. Olearchyk, N. Buckley, Ukraine gas deal loosens Russia's grip, 24.01.2013, http://www.ft.com/cms/s/0/f5decc00-6641-11e2-b967-00144feab49a.html\#axzz31UyNJ6tM (12.05.2014).

${ }^{49}$ R. Szoszyn, Rewolucja tupkowa na Ukrainie, „Rzeczpospolita”, 29.11.2013.

${ }^{50}$ Ch. Helman, What Ukraine Needs Is An American-Style Shale Gas Revolution, PortalForbes.com, 03.03.2014, http://www.forbes.com/sites/christopherhelman/2014/03/03/what-ukraine-needs-is-anamerican-style-shale-gas-revolution (12.05.2014). 
paliwa" do Unii, a więc nie tylko Rosja ${ }^{51}$. Niemniej jednak produkcja gazu z łupków jest szczególnie silnie kwestionowana przez Gazprom oraz rosyjskich wysokich urzędników państwowych. Perspektywa zwiększenia własnego wydobycia surowca oznacza osłabienie wieloletniej zależności od Rosji oraz ekonomiczne straty Gazpromu i rosyjskiego budżetu $^{52}$. Warto zauważyć, że minister przyrody i zasobów naturalnych Rosji skierował do swojego ukraińskiego odpowiednika pismo zawierające analizę ekologicznego ryzyka wydobycia gazu z łupków w obszarach przygranicznych obu państw. Rosjanie podnosili w swojej analizie, że w przygranicznych pokładach łupków brak jest buforowych złóż wodonośnych oraz skał, które stanowiłyby naturalną barierę dla chemikaliów, wykorzystywanych $\mathrm{w}$ metodzie szczelinowania. Tworzyłoby to, według ministra, zagrożenie skażenia wód gruntowych także na terenie Rosji ${ }^{53}$. W kontekście wielowymiarowych działan, zmierzających do przeciwdziałania „gazowej emancypacji” Ukrainy, można zrozumieć zagrożenie, jakie perspektywa ta budzi na Kremlu.

Warto wreszcie zwrócić uwagę na energetyczny, a w szczególności gazowy potencjał zajętego przez Rosję Krymu. Zasoby gazu na terytorium tego półwyspu szacuje się na $165,3 \mathrm{mld} \mathrm{m}^{3}$. Na obszarze Krymu istnieją 44 złoża węglowodorów, w tym 27 gazu ziemnego. Pięć pól gazowych znajduje się na szelfie Morza Czarnego, a sześć złóż tego surowca na Morzu Azowskim. Minister energetyki w rządzie Arsenija Jaceniuka, Jurij Prodan, stwierdził, że możliwe przychody $\mathrm{z}$ wydobycia gazu $\mathrm{z}$ łupków na Krymie mogą wynieść 40 mld USD ${ }^{54}$. Utrata Krymu oznaczała zatem znaczący cios zadany ukraińskim staraniom o zwiększenie bezpieczeństwa gazowego. Nie wydaje się jednakże prawdopodobny pogląd, aby złoża gazu łupkowego, które znajdują się nieopodal Słowiańska były przyczyną intensyfikacji działań rosyjskich komandosów w tym rejonie $^{55}$. Zajęcie Krymu, a także wciąż możliwe odłączenie się od Ukrainy innych terytoriów niewątpliwie osłabi bezpieczeństwo gazowe tego państwa, przynosząc znaczące korzyści Rosji.

\section{PERSPEKTYWY POZYSKIWANIA GAZU Z LUPKÓW}

Zasoby gazu niekonwencjonalnego na terytorium Ukrainy i na szelfie Morza Czarnego (gazu i hydratów gazu ziemnego tworzą specyficzny „metanowy pas Europy”, który w perspektywie dwóch najbliższych dekad mogłyby znacząco wpłynąc na zmianę geopolitycznej i geoekonomicznej sytuacji w regionie Europy Środkowo-Wschodniej. Sytuacja ta wywołuje sprzeciw Rosji, która posiada wszakże istotny atut w postaci możliwości transportu surowca. Kontrola nad gazociągami oznacza również kontrolę nad płynącym w nich surowcem oraz możliwość blokowania konkurencyjnych wobec dostaw Gazpromu wolumenów tego surowca, czyli w przyszłości również ukraińskiego gazu ze

\footnotetext{
${ }^{51}$ Zob. M. Ruszel, Gaz lupkowy podstawa bezpieczeństwa energetycznego Europy ŚrodkowoWschodniej, „Nowa Energia” 2011, nr 3(21), s. 84.

${ }^{52}$ T. Marocchi, T. Fedirko, op. cit., s. 6.

${ }^{53}$ I. Trusewicz, Rosja nie chce ukraińskich tupków, Portal Ekonomia.rzeczpospolita.pl, 17.01.2014, http://www.ekonomia.rp.pl/artykul/1079949.html (22.05.2014).

${ }^{54}$ ITAR-TASS News Agency, 11.04.2014, Ukraine estimates lost Crimean shale gas resources at $\$ 40$ billion, http://en.itar-tass.com/economy/727438 (15.05.2014).

${ }^{55}$ Центр Разумкова, 30.04.2014, Реальні запаси сланцевого газу в Украйні залишаються невідомими, http://www.razumkov.org.ua/ukr/expert.php?news_id=4750 (02.06.2014).
} 
źródeł niekonwencjonalnych ${ }^{56}$. Rosja może zatem w przyszłości torpedować ukraińskie próby dywersyfikacji źródeł wykorzystywanego gazu dzięki rurociągom powstałym jeszcze w czasach ZSRR. Wraz z gazociągami powstałymi już po rozpadzie Związku Radzieckiego, które omijają terytorium Ukrainy, stanowią one istotny oręż w rękach rosyjskich władz.

Sprzeciw wobec pozyskiwania gazu łupkowego zaznaczył się również w samej Ukrainie. Komuniści ogłosili zamiar przeprowadzenia referendum w sprawie zakazu wydobycia gazu nietradycyjnego. Władze zrezygnowały natomiast $\mathrm{z}$ przeprowadzenia kampanii informacyjnej w mediach oraz współpracy $\mathrm{z}$ miejscowymi radnymi, z czego skorzystali przeciwnicy gazu łupkowego. Rolę platform dialogu próbują wziąć na siebie organizacje zrzeszające ekspertów: Związek Geologów Ukrainy, Kijowski Międzynarodowy Energetyczny Q-Club czy Związek Pracowników Przemysłu Wiertniczego, będący znaną i cieszącą się autorytetem niezależną i bezstronną organizacją. Problem wydobycia gazu niekonwencjonalnego stał się wręcz elementem walki politycznej. Co ciekawe, spośród parlamentarnych partii opozycyjnych, jedynie UDAR wspiera wydobycie gazu z łupków na Ukrainie. Największym przeciwnikiem wydobycia tego surowca stała się partia Swoboda. Przeciwni pozyskiwaniu gazu z łupków są również organizacje ekologiczne ${ }^{57}$, akcentujące zagrożenia dla środowiska, jakie płyną z wykorzystywania technologii szczelinowania hydraulicznego.

Biorąc pod uwagę fakt, że w przypadku produkcji na dużą skalę gazu z łupków na Ukrainie, jego cena będzie wynosić prawdopodobnie połowę ceny gazu rosyjskiego, w przyszłości istnieje możliwość znacznego zwiększenia bezpieczeństwa energetycznego Ukrainy $^{58}$. Według raportu IHS CERA „Gaz ziemny i przyszłość energetyczna Ukrainy”, sporządzonego na zamówienie Ministerstwa Energetyki i Przemysłu Węglowego Ukrainy w 2012 roku, przemysłowa eksploatacja gazu niekonwencjonalnego i osiągnięcie poziomu wydobycia gazu niekonwencjonalnego $\mathrm{w}$ wysokości $25 \mathrm{mld} \mathrm{m}^{3}$ rocznie, jest możliwe pod warunkiem, że inwestycje w złoża wyniosą 2-3,5 mld USD rocznie, a w pewnych okresach nawet 10 mld USD ${ }^{59}$. Należy jednak zauważyć, że Chevron i Shell wycofały się z poszukiwań gazu niekonwencjonalnego, za czym może przemawiać zarówno zagrożenia płynące z konfliktu zbrojnego, jak i zbyt wysokie podatki od wydobywania zasobów mineralnych.

Firmy będą pracowały na tzw. platformie odeskiej, która zawiera złoża łupków w rejonie lwowskim i iwano-frankowskim. Ich gazowe zasoby są szacowane na $3 \mathrm{bln} \mathrm{m}^{3}$. Kijów liczy, że rocznie otrzyma od 5 do $10 \mathrm{mld} \mathrm{m}^{3}$ gazu. Przy uwzględnieniu istniejącego popytu, wynoszącego 50-60 mld $\mathrm{m}^{3}$ gazu rocznie, zasoby takie wystarczyłyby Ukraińcom na około 200 lat $^{60}$. We wrześniu 2013 roku premier Mykoła Azarow oświadczył, że cena gazu z łupków będzie wynosić 120-130 USD za $1000 \mathrm{~m}^{3}{ }^{61}$ Były unijny Komisarz ds. energii, Günther Oettinger, stwierdził nawet, że Ukraina może eksportować gaz do

\footnotetext{
${ }^{56}$ M. Honczar, op. cit.

${ }^{57}$ Ibidem.

${ }^{58}$ T. Marocchi, T. Fedirko, op. cit., s. 10.

${ }^{59}$ M. Honczar, op. cit.

${ }^{60}$ I. Trusewicz, op. cit.

${ }^{61}$ R. W. Lijdsman, Unconventional Gas in Ukraine: Boom or Bust, Portal U.S.-Ukraine Foundation, http://www.usukraine.org/bizlinks/Reports/UnconventionalGasinUkraineBoomorBust.pdf (12.05.2014)
} 
Europy $^{62}$. Opinię tę należy uznać za nazbyt optymistyczną, zwłaszcza w sytuacji, kiedy brak jeszcze danych na temat rzeczywistych zasobów Ukrainy. Trzeba jednakże zauważyć, że pozyskanie gazu (konwencjonalnego i niekonwencjonalnego), znajdującego się, według istniejących szacunków, na obszarze Ukrainy, dałoby jej możliwość dużo bardziej swobodnego kształtowania relacji z Rosją. Trudna sytuacja wewnętrzna, a także wskazane już wcześniej przyczyny, mogą jednak znacząco przeszkodzić polepszeniu gazowego bezpieczeństwa Ukrainy.

Jak już wspomniano, wraz z rozwojem projektów wydobycia gazu z łupków można oczekiwać narastania prób ich zablokowania ze strony Rosji. Mając na celu utrzymanie uzależnienia Ukrainy od rosyjskiego gazu, Moskwa będzie inspirować i wspierać przeciwników pozyskiwania gazu z łupków. Jak wskazano już wcześniej, jednym z instrumentów storpedowania przez Rosję projektów wydobycia gazu może stać się przejęcie przez Gazprom kontroli nad ukraińskimi gazociągami tranzytowymi ${ }^{63}$. W obecnej sytuacji politycznej, perspektywa utworzenia ukraińsko-rosyjskiego konsorcjum gazowego nie jest jednak możliwa. Pewien problem stanowi fakt, iż większość gazu z łupków oraz metanu z pokładów węgla na Ukrainie znajduje się na wschodzie państwa, a więc na obszarach, na których toczą się walki z separatystami.

\section{WNIOSKI}

Mając na uwadze istniejące uwarunkowania, należy stwierdzić, że istnienie na Ukrainie znaczących zasobów gazu $\mathrm{z}$ łupków, mogących częściowo pokryć zapotrzebowanie tego państwa na surowiec, jest faktem. Bogate zasoby mogą w przyszłości $\mathrm{w}$ pewnym stopniu pomóc temu państwu w wyemancypowaniu się spod wpływów Rosji, choć na obecnym etapie trudno o dokładniejsze szacunki odnośnie istniejących zasobów oraz możliwości ich komercyjnego wykorzystania.

W toku przedstawionych rozważań należy również stwierdzić, że aktywność zachodnich koncernów w poszukiwaniu gazu z łupków jest znacząca i mogą one odkrywać kolejne złoża gazu, w tym także pochodzące $\mathrm{z}$ formacji łupkowych. W poszukiwaniach gazu ze złóż niekonwencjonalnych na terytorium Ukrainy biorą udział liczne zachodnie firmy, aktywne w tym zakresie także w innych częściach świata. Pomimo istniejących przeszkód, aktywnie rozpoznają one znajdujące się na Ukrainie złoża nie tylko gazu z łupków, lecz także gazu ściśniętego oraz metanu z pokładów węgla.

Wydaje się, że pogląd, iż projekty łupkowe mogą pomóc uniezależnić się od importu gazu z Rosji jest wiarygodny o tyle, że surowiec ten może w pewnym stopniu pokryć zapotrzebowanie Ukrainy. Pozyskiwanie gazu niekonwencjonalnego, w tym również gazu z łupków, nieprędko doprowadzi jednak do znaczącego wzmocnienia Ukrainy w gazowych relacjach z Rosją. Pomimo pewnego zaangażowania prac poszukiwawczych, jest jeszcze zbyt wcześnie, aby ocenić na ile realne są przewidywania co do rzeczywistych zasobów gazu z łupków na terytorium Ukrainy. Poszukiwaniom surowca nie sprzyjają również wysokie opłaty, związane z bardzo trudną sytuacją finansową tego państwa.

Sukces prac nad pozyskaniem gazu ziemnego ze złóż niekonwencjonalnych doprowadziłby wszakże do pokrycia części zapotrzebowania państwa na ten surowiec, co

\footnotetext{
${ }^{62}$ Slanceviy-glas.livejournal.com, 04.02.2014, Г. Эттингер предположил, что Украина может стать экспортером газа в Европy, http://slanceviy-glas.livejournal.com/114756.html (03.06.2014).

${ }^{63}$ M. Honczar, op. cit.
} 
z kolei wzmocniłoby pozycję Kijowa wobec Moskwy. Należy stwierdzić, że istnieje szansa na dywersyfikację dostaw energii na Ukrainie oraz na osłabienie nacisków politycznych z północno-wschodniego sąsiada istnieje, a nowe władze państwa mogą, w razie potwierdzenia się informacji o zasobach gazu, uczynić z tego atutu ważki argument w relacjach ze wschodnim sąsiadem. Już jednak obecnie informacje na temat intensyfikacji prac nad pozyskiwaniem gazu niekonwencjonalnego stanowią poważny atut Kijowa w rozmowach z Moskwą.

Podstawowe kontrowersje, związane z wydobywaniem gazu z łupków, związane są z zagrożeniami, jakie technika pozyskiwania tego surowca może nieść dla środowiska. Przeciwnicy technologii szczelinowania hydraulicznego wyrażają swój protest w różnych częściach świata, w tym także na Ukrainie. Problem wydobycia gazu ze złóż niekonwencjonalnych stał się wręcz elementem walki politycznej pomiędzy partiami i organizacjami społecznymi. Swój sprzeciw zgłaszają zwłaszcza, podobnie jak w innych państwach, organizacje ekologiczne.

Zaangażowanie Ukrainy w pozyskiwanie gazu z łupków wzbudza niechęć Rosji, która $\mathrm{z}$ tytułu dostaw surowca czerpie wymierne korzyści. Warto zauważyć, że rosyjskie władze, wielokrotnie stosujące wobec władz w Kijowie „szantaż energetyczny”, prowadzące kampanię propagandową przeciwko pozyskiwaniu gazu $\mathrm{z}$ łupków. Poszukiwania tego gazu na Ukrainie utrudniają także toczące się działania wojenne. Jak zostało to wykazane, z uwagi na znajdujące się na Krymie złoża gazu z łupków, aneksja półwyspu oznaczała poważny cios zadany ukraińskim staraniom o zwiększenie bezpieczeństwa gazowego. Postępująca destabilizacja sytuacji na Ukrainie stanowi zarazem korzyść dla Rosji, starającej się osłabić pozycję władz w Kijowie, aby zdezintegrować państwo i aktywność jego władz, także w sferze energetycznej. Dodatkowym wzmocnieniem pozycji Kijowa byłoby również uruchomienie dostaw LNG, a perspektywa dostaw surowca tą drogą nie stanowi dla Ukrainy odległej perspektywy.

\section{LITERATURA}

[1] Andoura S., Security of Supply and the External Dimension of a European Energy Policy, „Studia Diplomatica” 2007, vol. LX, no 2.

[2] Bodio M., Polityka energetyczna $w$ stosunkach między Unia Europejska a Federacja Rosyjska w latach 2000-2008, Warszawa 2009

[3] BP Statistical Review of Global Energy, June 2013, http://www.bp.com/content/dam/bp/pdf/statistical-

review/statistical_review_of_world_energy_2013.pdf (23.05.2014)

[4] Brzeziński Z., Wielka szachownica, Warszawa 1999

[5] Center EIR, Центр досліджень енергетики, 10.09.2013, Енергетична стратегія Украӥни на період до 2030 року (проект), http://eircenter.com/uaanaliitika/energetichna-strategiya-ukrayini-na-period-do-2030-r-proekt (20.05.2014)

[6] Dąborowski T., Priorytety wspótpracy gazowej w Europie PoludniowoWschodniej, „Analizy OSW”, 15.07.2015, http://www.osw.waw.pl/pl/publikacje/analizy/2015-07-15/priorytety-wspolpracygazowej-w-europie-poludniowo-wschodniej (24.10.2015)

[7] Diec J., Jach A., red., Fenomen Rosji. Pamięć przeszłości i perspektywy rozwoju. Część 2: Kontekst polityczny i gospodarczy, Kraków 2014 
[8] EIA/ARI World Shale Gas and Shale Oil Resource Assessment, Arlington, June 2013

[9] Gil W., Gil N., Stosunki Polski z Ukraina w latach 1989-1993, ToruńPoznań 1994

[10]Helman Ch., What Ukraine Needs Is An American-Style Shale Gas Revolution, Portal Forbes.com, 03.03.2014, http://www.forbes.com/sites/christopherhelman/2014/03/03/what-ukraine-needsis-an-american-style-shale-gas-revolution (12.05.2014)

[11]Honczar M., Pierwsze kroki w nieznane. Perspektywy wydobycia gazu niekonwencjonalnego na Ukrainie, „Komentarze OSW”, 27.04.2013, http://www.osw.waw.pl/pl/publikacje/komentarze-osw/2013-04-27/pierwszekroki-w-nieznane-perspektywy-wydobycia-gazu (01.06.2014)

[12] International Energy Agency, Key World Energy Statistics 2005, Paris 2005

[13] International Energy Agency 2012, Ukraine 2012

[14]ITAR-TASS News Agency, 11.04.2014, Ukraine estimates lost Crimean shale gas resources at $\$ 40$ billion, http://en.itar-tass.com/economy/727438 (15.05.2014)

[15] Kapuśniak T., Pozycja ekonomiczna Ukrainy, [w:] Ukraina w stosunkach międzynarodowych, red. M. Pietraś, T. Kapuśniak, Lublin 2007

[16] Kęsek R., Między konfliktem a dialogiem. Polityka Ukrainy wobec Federacji Rosyjskiej w latach 1997 -2004, Kraków 2010

[17] Kost P., Ukraina wobec Unii Europejskiej 1991-2010, Toruń 2012

[18] Kozakiewicz J., Rosja w polityce niepodległej Ukrainy, Warszawa 1999

[19]Lijdsman R. W., Unconventional Gas in Ukraine: Boom or Bust, Portal U.S.-Ukraine $\quad$ Foundation, http://www.usukraine.org/bizlinks/Reports/UnconventionalGasinUkraineBoomor Bust.pdf (12.05.2014)

[20] Marocchi T., Fedirko T., Shale gas in Poland and Ukraine: a great potential and an uncertain future, „Pecob-Business Reports”, May 2013

[21] Mickiewicz P., Sokołowska P., red, Bezpieczeństwo energetyczne Europy Środkowej, Torun 2010

[22] Moenke A., Wplyw rewolucji tupkowej w Stanach Zjednoczonych Ameryki na rosyjskie plany rozwou sektora LNG, [w:] Fenomen Rosji. Pamięć przeszłości i perspektywy rozwoju. Część 2: Kontekst polityczny i gospodarczy, red. J. Diec, A. Jach, Kraków 2014

[23] Nowacki M., Prawne aspekty bezpieczeństwa energetycznego w UE, Warszawa 2010

[24] Olearchyk R., Buckley N., Ukraine gas deal loosens Russia's grip, 24.01.2013, http://www.ft.com/cms/s/0/f5decc00-6641-11e2-b96700144feab49a.html\#axzz31UyNJ6tM (12.05.2014)

[25]Pietraś M., Kapuśniak T., red., Ukraina w stosunkach międzynarodowych, Lublin 2007

[26] Gazownictwo.wnp.pl, 03.10.2013, Ukraina przeszacowuje plany uniezależnienia się od gazu z Rosji, http://gazownictwo.wnp.pl/ukrainaprzeszacowuje-plany-uniezaleznienia-sie-od-gazu-z-rosji,208029_1_0_0.html $(22.05 .2014)$ 
[27] Gospodarczy wnp.pl, 03.10.2013, Ukraina przeszacowuje plany uniezależnienia się od gazu $z$ Rosji, http://gazownictwo.wnp.pl/ukrainaprzeszacowuje-plany-uniezaleznienia-sie-od-gazu-z-rosji,208029_1_0_0.html (02.06.2014).

[28] Razemolupkach.org, Ukraiński gaz tupkowy - Ukraina traci kontrakty?, http://www.razemolupkach.org/node/1140 (12.05.2014)

[29] Reuters.com, 11.05.2012, Ukraine picks Shell, Chevron to develop shale gas fields, http://www.reuters.com/article/2012/05/11/shell-chevron-ukraineidUSL5E8GBAE020120511 (12.05.2014)

[30]Pyka J., Rola Rosji w zapewnieniu globalnego bezpieczeństwa energetycznego, [w:] Bezpieczeństwo energetyczne Europy Środkowej, red. P. Mickiewicz, P. Sokołowska, Toruń 2010

[31] Ruszel M., Gaz łupkowy podstawa bezpieczeństwa energetycznego Europy Środkowo-Wschodniej, „Nowa Energia” 2011, nr 3(21)

[32] Sarna A., Gazowa strategia Kijowa: między Gazpromem a realna dywersyfikacja, $\quad$ „Komentarze OSW”, 15.07.2013, http://www.osw.waw.pl/pl/publikacje/komentarze-osw/2013-07-15/gazowastrategia-kijowa-miedzy-gazpromem-a-realna (22.05.2014)

[33] Sarna A., Umowa Ukrainy z koncernem Shell o wydobyciu gazu tupkowego, „Analizy OSW”, 30.01.2013,

http://www.osw.waw.pl/pl/publikacje/analizy/2013-01-30/umowa-ukrainy-z-

koncernem-shell-o-wydobyciu-gazu-lupkowego (31.05.2014)

[34] Slanceviy-glas.livejournal.com, 04.02.2014, Г. Эттингер предположил, что Украина может стать экспортером газа в Европу, http://slanceviyglas.livejournal.com/114756.html (03.06.2014).

[35]Sydun S., Ewolucja stosunków pomiędzy Ukraina $i$ UE, „Środkowoeuropejskie Studia Polityczne” 2010, t. 3.

[36] Szoszon R., Rewolucja tupkowa na Ukrainie, „Rzeczpospolita”, 29.11.2013

[37]Trusewicz I., Rosja nie chce ukrainskich tupków, Portal Ekonomia.rzeczpospolita.pl,

17.01.2014 http://www.ekonomia.rp.pl/artykul/1079949.html (22.05.2014)

[38]Ukraine Special Report, Natural Gas and Ukraine's Energy Future, February 2012, http://s05.static-shell.com/content/dam/shellnew/local/country/zaf/downloads/pdf/research-reports/Ukraine-Policy-Dialoguereport.pdf (14.05.2014)

[39] Ukraina nie będzie pompowała więcej gazu do magazynów, Portal gospodarczy Wnp.pl, 03.11.2015, http://gazownictwo.wnp.pl/ukraina-nie-bedziepompowala-wiecej-gazu-do-magazynow,260592_1_0_0.html (29.03.2016).

[40] Wieroński M., Ukraina stawia na własny gaz tupkowy, Centrum Informacji o Rynku Energii, 18.02.2013,

http://www.cire.pl/item,72091,1,0,0,0,0,0,ukraina-stawia-na-wlasny-gaz-

lupkowy.html (12.05.2014)

[41]Zachmann G., Naumenko D., Evaluating the options to diversify gas supply in Ukraine, Berlin/Kyiv, February 2014

[42]Вилінський С. I., Розвиток альтернативих видів палива в Украӥні. Сланцевий газ та Україна, „Актуальні проблеми міжнародних відносин”, Випуск 116 (Частина I), 2013 
[43]Гончар М. М., Енергетична безпека Украӥни: біг на місиі, [w:] Г. М. Перепелица (ред.), Зовнішня політика України, Київ 2009

[44]Енергетична стратегія України на період до 2030 p., http://zakon5.rada.gov.ua/laws/show/1071-2013-\%D1\%80/paran4\#n4 (03.04.2016).

[45]Закон Украӥни. Про затвердження Загальнодержавної програми розвитку мінерально-сировинної бази України на період до 2030 року, http://zakon5.rada.gov.ua/laws/show/3268-17 (30.03.2016).

[46] Міністерство енергетики та вугільної промисловості України, 19.04.2006, Енергетична стратегія України на період до 2030 р., http://mpe.kmu.gov.ua/fuel/control/uk/doccatalog/list?currDir=50358

(01.06.2014)

[47]Перепелица Г. М., ред., Зовнішня політика України, Київ 2009

[48] Центр Разумкова, 30.04.2014, Реальні запаси сланцевого газу в Украӥні залишаються

невідомими

http://www.razumkov.org.ua/ukr/expert.php?news_id=4750 (02.06.2014)

PROSPECTS FOR EXTRACTING SHALE GAS IN UKRAINE

The discovery of shale gas in the area of Ukraine can provide a significant support for a country which would like to become independent of gas supplies from the East. This is particularly important in the time of tension between Russia and Ukraine when the importance of gas as a pressure element has increased even more. Once the information about significant shale gas deposits in Ukraine is confirmed this may improve position of the country fighting for independence and territorial integrity as well as diversifying sources of natural gas supplies. The paper presents estimates of the Ukrainian gas resources and the demand for raw materials in the country. It shows the action of Ukraine, aiming at supplies diversification and even partial independence from Russia. Further the author describes the activities of the western companies that deal with prospecting for shale gas as well as shows the most important raw material deposits in the area where the work is taking place. As Russia is a key supplier of gas to Ukraine, the article also presents a critical attitude of Moscow towards shale gas in Ukraine. The seizure of the Crimea and possible separation of other territories from the Ukraine have proved to undoubtedly weaken the gas security of that country, bringing significant benefits to Russia. The article also presents the perspectives of extracting shale gas in Ukraine, in particular, objections of certain political and social forces. Importantly, the article also stresses the importance of other types of unconventional gas: tight gas and coalbed methane.

Keywords: Ukraine, shale gas, prospects.

DOI:10.7862/rz.2016.hss.36

Przesłano do redakcji: wrzesień 2014

Przyjęto do druku: styczeń 2016 